Keywords: Suicide; Risk factors; Neurobiology;

Genetics; Child abuse; Endophenotype.

\title{
Neurobiological underpinnings of suicidal behavior: Integrating data from clinical and biological studies
}

\author{
Juan J. Carballo* \\ Dianne Currier ${ }^{\star *}$ \\ Ana E. Figueroa* \\ Lucas Giner*** \\ Samuel Aidan Kelly** \\ M. Elizabeth Sublette ${ }^{* \star}$ \\ Maria A. Oquendo**
}

* Department of Child and Adolescent

Psychiatry. University Clinic,

University of Navarre

** New York State Psychiatric Institute and the College of Physicians and Surgeons of Columbia University, New York

*** Department of Psychiatry. University of Seville

SPAIN

\begin{abstract}
Background and Objectives: Every year, suicide accounts for approximately one million preventable deaths worldwide. Suicidal behavior is complex and multi-determined with risk factors identified in multiple domains including clinical, genetic, environmental, behavioral, neurophysiological, and neurocognitive. Modeling causal pathways that integrate these factors may assist in better identification of high-risk individuals would allow for effective preventive intervention.

Methods: Published literature in the English language was reviewed to identify evidence supporting a multi-dimensional model of putative causal pathways for suicidal behavior.

Results: There is evidence that clinical, neurochemical, neuroendocrine, neurocognitive, and neurophysiological contributory factors may be useful as intermediate phenotypes in describing putative causal pathways from genetics and early-life adversity to suicidal acts.

Conclusions: Determining the causes of suicidal behavior involves integrating risk factors from multiple domains.
\end{abstract}




\section{Introduction}

Suicide accounts for approximately one million deaths a year worldwide ${ }^{1}$, and has devastating personal, family, and socioeconomic consequences. In the USA, it is the eleventh leading cause of death for all ages, and in 2005 suicide accounted for approximately 32,000 deaths, $1.3 \%$ of all deaths in the U.S ${ }^{2}$. The US suicide rate in 2005 was $11 / 100,000$, with a rate of $17.7 / 100,000$ in males and 4.5/100,000 in females ${ }^{2}$. Although lower than the USA, suicide rates in Spain for the same period, were also high: $12.0 / 100,000$ in males and 3.9/100,000 in females ${ }^{1}$. In the US, suicide is the fifth leading cause of years of potential life lost before the age of $65^{2}$. The impact of suicidal behavior is even greater than the death rates suggests, because it not only involves the older population, but also markedly affects adolescents and young adults. In 2007, $14.5 \%$ of U.S. high school students reported they had seriously considered suicide during the preceding year, and more than $6.9 \%$ reported they had actually attempted suicide one or more times during the same period ${ }^{3}$. For every suicide death in the 15 to 24 yearold age group, it is estimated that 100 to 200 attempts are made ${ }^{4}$.

Over $90 \%$ of those who die by suicide have a psychiatric illness, with $60 \%$ of all suicides occurring in the context of a mood disorder ${ }^{5}$. Suicide attempt rates are also elevated among individuals with psychiatric disorders, with reported rates of suicide attempt of $29 \%$ in Bipolar disorder, $16 \%$ in Major Depressive Disorder ${ }^{6}, 16-29 \%$ in alcohol use disorders $^{7-10}$, and $23-30 \%$ in psychotic disorders ${ }^{11,12}$, compared to $4.6 \%$ reported in general population surveys ${ }^{13}$. However, the majority of psychiatric patients do not attempt suicide, so a more specific explanation for suicidal behaviour must be sought.
Many factors have been associated with suicide attempt and suicide in studies of clinical populations, including abnormal serotonergic, noradrenergic system and HPA axis function, deficits in executive function, smoking, and higher aggression, impulsivity, hopelessness, and pessimism ${ }^{14-16}$.

There is no single causal factor for suicidal behavior. Rather, it has been proposed that suicidal behavior occurs in the context of an interaction between a diathesis for suicidal behavior and the occurrence of acute stressors ${ }^{17}$. The diathesis refers to an individual's predisposition to manifest suicidal behavior in response to a stressor, is considered trait based, and is independent of psychiatric condition ${ }^{17}$. The diathesis for suicidal behavior is hypothesized to comprise factors or traits from multiple domains including biological, genetic, cognitive, personality, behavioral, and clinical (see ${ }^{18}$ for an overview). Stressors act as triggers or precipitants and relate to both the timing and probability of suicidal acts and are considered state-related ${ }^{17}$. Stressors may include a major depressive episode, acute substance intoxication, or personal stressors (familial, social, or financial). Thus, suicidal behavior is not simply a reaction to extreme stress, nor does it necessarily correlate with the severity of a stressor, but results instead from the interaction of the individual's diathesis or predisposition to engage in suicidal acts and the occurrence of a trigger ${ }^{17}$. Given the multiple contributory causal factors, both in the diathesis and stressor domains, an explanatory model for suicidal behavior must be able to integrate risk factors into a multidimensional model that includes clinical, biological, genetic, behavioral, personality, and psychosocial traits as well as stressors and delineate causal pathways leading to suicidal outcomes. 


\section{An Integrated Model of Suicidal Behavior}

The endophenotype approach is particularly relevant to the study of complex multidetermined behaviors such as suicide and suicide attempt. An endophenotype is an intermediary phenotype in the etiologic pathway from genes to disease ${ }^{19}$, and represent more basic constructs, symptoms, or characteristics that are more amenable to quantification $^{19}$. Beyond focusing on the casual pathways between genes and suicidal behavior, the concept of an intermediary phenotype can also be useful as an approach to tracing the etiological pathways from observed neurochemical, neuroendocrine, and neurophysiological dysfunction to suicidal outcomes via behavioral, clinical, and cognitive alterations. In figure 1 we outline a putative model of suicidal behavior which originates with genetic and environmental factors and then delineates clinical, biological, and other risk factors identified in the literature, that may function as endophenotypes. Developing such explanatory models is a crucial step not only for identifying areas which require further investigation, but also for improving assessment of risk for suicidal behavior and identifying targets for preventive intervention. We will first outline some putative clinical, biological, and neurocognitive endophenotypes and describe the relationship between them, and then examine genetic and environmental considerations.

\section{Clinical Endophenotypes}

Clinical traits repeatedly associated with suicide attempt and suicide death across psychiatric diagnostic groups include impulsivity, aggression, pessimism, and hopelessness (for a review see ${ }^{20}$ ). However, they are not sufficient to explain suicidal behavior, and these constructs or traits themselves are often complex or may be too loosely defined. For example, there are many types of impulsivity, which may potentially result from different underlying neurobiological anomalies ${ }^{21}$. Moreover, clinical traits may be causally interrelated, for example both pessimism and aggression/impulsivity predict suicidal acts, but they also have an additive

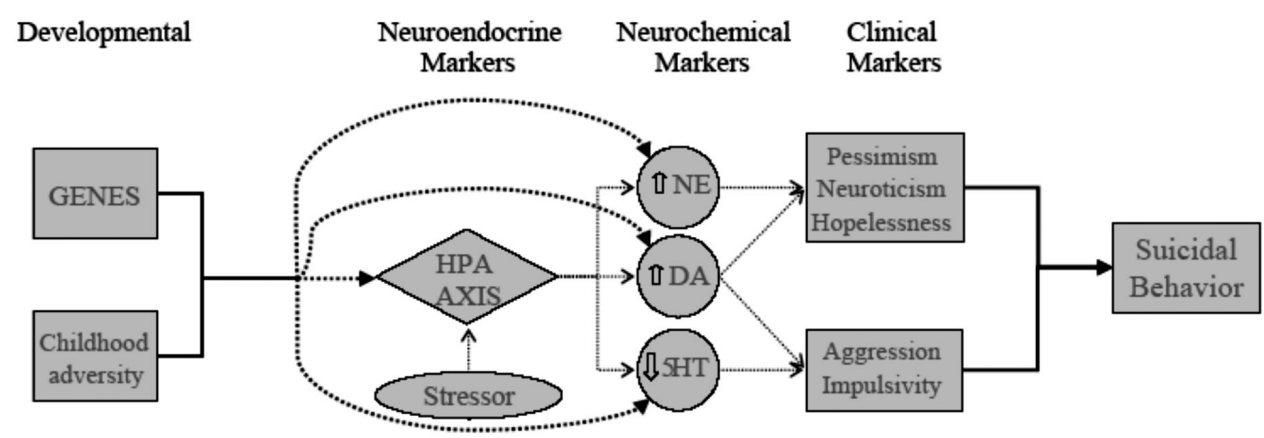

Causal Factors?

Endophenotypic Markers for Suicidal Acts 
effect on suicide attempt risk ${ }^{22}$. Addressing this complexity may require defining more precise constructs, and contextualizing traits in terms of related biological, genetic, and other domains of risk, so that a more finegrained assessment of the relevance of such traits to suicidal behaviors is possible.

\section{Neurochemical Endophenotypes}

Biological studies have examined the role of the serotonergic, noradrenergic, and dopaminergic systems in suicidal behavior, as well at the HPA axis stress response system.

\section{Serotonergic system}

The most consistent finding in suicidal individuals is dysfunction in the serotonergic system ${ }^{16}$. In suicide, altered serotonergic function has been evidenced in studies of the serotonin metabolite 5-hydroxyindoleacetic acid in cerebrospinal fluid (CSF 5HIAA), and of serotonin receptors and transporters in postmortem brain ${ }^{23-26}$. In a metaanalysis of prospective studies, individuals with below median levels of CSF 5HIAA were 4.5 times more likely to die by suicide than those in the above median group $^{27}$. Lower concentration of CSF 5HIAA has also been reported particularly in individuals who use violent methods to suicide or make higher lethality non-fatal attempts ${ }^{28-31}$. Postmortem studies of the brain in individuals who have died by suicide indicate a localized reduction in serotonin transporter (SERT) binding in the ventral prefrontal cortex, which could reflect reduced serotonin input in this area ${ }^{32,33}$. SERT mRNA is found in the serotonergic neurons of the dorsal raphe nucleus and median raphe nucleus ${ }^{34}$. Some hypothesize that findings in suicide victims of increased tryptophan hydroxylase, reduced SERT mRNA, and reduced number of 5- $\mathrm{HT}_{1 \mathrm{~A}}$ inhibitory autoreceptors, are homeostatic mechanisms that arise secondary to serotonergic deficit ${ }^{34}$.

In support of a role for altered serotonergic function in suicidal behavior in vivo imaging studies report lower C- $\alpha$-methylL-tryptophan trapping in the orbital and ventromedial prefrontal cortex in highlethality suicide attempters, with a negative correlation with suicide intent ${ }^{35}$, and a negative correlation of 5- $\mathrm{HT}_{2 \mathrm{~A}}$ binding with levels of hopelessness, a correlate of suicide and suicide attempt ${ }^{36}$. Oquendo et al., in a PET study, reported found that in response to the administration of the serotonin agonist fenfluramine, depressed high-lethality suicide attempters had lower fluorodeoxyglucose $\left({ }^{18} \mathrm{~F}\right)$ regional cerebral metabolism of glucose rCMRGlu) in anterior cingulate and superior frontal gyri, compared with depressed low-lethality attempters ${ }^{26}$. In that study, lethality of the most serious lifetime suicide attempt correlated negatively with rCMRGlu in the anterior cingulate, right superior frontal, and right medial frontal gyri suggesting prefrontal cortex hypofunction in high-lethality depressed suicide attempters ${ }^{26}$.

Altered serotonergic function has been associated with certain clinical traits mentioned above. There is substantial literature supporting the role of serotonergic function in aggressive $\mathrm{e}^{37}$ and, to a lesser extent, impulsive ${ }^{21}$ behavior. This is consistent with observations that alterations in SERT binding associated with higher risk for suicide appear to be concentrated in the ventral PFC, known to mediate inhibition and restraint $^{32,33}$. Additionally prefrontal hypofunction and impaired serotonergic responsivity are related to the lethality of a suicide 
attempt suggesting that aggression may be an intermediate clinical phenotype for serotonergic dysfunction and suicidal behavior ${ }^{26}$. Other brain imaging studies offer support for this, reporting lower serotonin transporter binding in the frontal and midbrain regions in impulsive violent subjects ${ }^{38}$ and inverse correlation between $5-\mathrm{HT}_{1 \mathrm{~A}}$ binding in the orbital frontal cortex and aggression scale scores $^{39}$. Altered serotonin function has also been associated with other clinical traits related to suicidal behavior, including pessimism and dysfunctional attitudes ${ }^{40,41}$ and hopelessness ${ }^{36,42}$.

\section{Noradrenergic function}

Suicidal and depressed patients have a decreased number of norepinephrine (NE) neurons in the locus ceruleus ${ }^{43}$. Secondary to lower NE levels, greater $\beta$-adrenergic cortical receptor binding (downregulation) ${ }^{44}$, and lower $\alpha$-adrenergic binding (upregulation $)^{45}$ have been reported. These changes are suggestive of cortical noradrenergic overactivity that may be attributable to $\mathrm{NE}$ depletion from the smaller population of $\mathrm{NE}$ neurons found in suicide victims ${ }^{46}$. Moreover, the exaggerated sympathetic responses to stress exhibited by individuals with a history of childhood trauma ${ }^{44}$ might further deplete NE function ${ }^{47}$. In cross-sectional studies lower cerebrospinal fluid 3-methoxy-4-hydroxphenylglycol (CSF MHPG), a metabolite of noradrenalin, has been reported in suicide attempters compared to non-attempters in major depression ${ }^{48}$ and a sample of criminal offenders ${ }^{49}$, however the majority of crosssectional studies observe no differences (reviewed in ${ }^{50}$ ). Prospective studies, potentially better suited to tracking state-dependent noradrenergic stress response, have also produced inconsistent results, with one study reporting that individuals who engaged in repeat suicidal behavior in the year following hospitalization for a suicide attempt were more likely to have above median CSF MHPG levels ${ }^{51}$, and others finding no association with future suicide $23,52,53$ or suicide attempt ${ }^{29,31}$. However, a recent prospective study using survival analysis techniques found lower baseline CSF MHPG was associated with increased risk of making a fatal or nonfatal suicide attempt in the 12 months following a major depressive episode ${ }^{54}$.

In studies of the relationship of noradrenergic function and clinical endophenotypes for suicidal behavior, higher NE concentrations are shown to be associated with higher levels of aggression ${ }^{16}$ and increased CSF MHPG with greater hostility ${ }^{55}$. Catecholamine depletion resulted in an increase in hopelessness in remitted depressed individuals treated with $\mathrm{NRIs}^{56}$, consistent with preclinical studies suggesting NE intervenes in the development of pessimism and hopelessness ${ }^{57}$.

\section{Dopaminergic function}

Altered function in the dopaminergic system has been found in depressive disorders and alcohol use disorders ${ }^{58}$, however the role of the dopaminergic system in suicidal behavior is uncertain as the abnormalities observed in some studies may be attributable to depression ${ }^{16,59}$. Reduced dopamine turnover, indicated by low dihydroxyphenylacetic acid levels, was found in the caudate, putamen, and nucleus accumbens reported in depressed suicides ${ }^{60}$. In another study, the same group found no difference in number or affinity of the dopamine transporters ${ }^{61}$, suggesting it is unlikely that the reduced dopamine turnover initially observed is a result of decreased dopaminergic innervation of those regions. Prospective studies disagree as to whether the dopamine metabo- 
lite homovanillic acid (HVA) levels in CSF predict suicidal behavior ${ }^{51,62-64}$. In terms of clinical endophenotypes for suicidal behavior and dopaminergic function, higher CSF HVA levels correlate with increased aggression (for a review see Ryding ${ }^{37}$ ) and striatal dopamine D2 receptor binding was correlated with neuroticism scores in a healthy community sample ${ }^{65}$.

\section{Neuroendocrine Endophenotypes}

\section{Hypothalamic-Pituitary- Adrenal Axis}

Postmortem studies of suicides have reported fewer corticotrophin releasing hormone $(\mathrm{CRH})$ receptor binding sites in the frontal cortex ${ }^{66}$ and increased CRH concentrations in $\mathrm{CSF}^{67}$. Hyperactivity of the HPA axis has been associated with suicidal behavior evidenced by a failure to suppress cortisol secretion following the administration of Dexamethasone (DST). Coryell et al. estimate that DST non-suppressors have a 14-fold higher risk of suicide compared to suppressors $^{68}$. However, DST non-suppression is also associated with posttraumatic stress disorder and depression, and these conditions may mediate the relationship of dexamethasone nonsuppression to suicidal behavior $^{69}$. In non-fatal suicide attempt, DST response is an uncertain indicator of risk, with the majority of prospective studies finding no association between DST nonsuppression and future suicide attempt, although a small number find an association with serious or violent attempts ( $\mathrm{see}^{70}$ for a review). In other indices of HPA axis function there are reports of lower CSF CRH but no difference in plasma CRH or plasma cor- tisol $^{71}$, higher urinary cortisol in violent attempters $^{72}$, and higher serum cortisol after 5-hydroxytryptophan administration ${ }^{73}$. DST findings provide strong support for a role of abnormal HPA axis mediated physiological stress response in suicide, however the role in non-fatal suicidal behavior requires further elucidation.

\section{HPA axis and neurotransmitters}

The HPA axis has complex relationships with the serotonergic, noradrenergic, and dopaminergic systems, further complicating the biological picture. The HPA axis has a bidirectional relationship with the serotonergic system ${ }^{74}$. CRH neurons of the central amygdala are connected to the raphe nuclei $^{75}$, the principal serotonin source to the forebrain. Projections from the raphe nuclei extend to various brain regions that contain $\mathrm{CRH}$ and participate in the stress response $\mathrm{e}^{75}$. HPA hyperactivity observed in suicidal patients may mediate or moderate some of the serotonin abnormalities found in these patients $^{76}$, and corticosteroid modulation of serotonin receptors as a response to stress may have important implications for the pathophysiology of suicide ${ }^{59,76}$. The HPA axis also has a bidirectional relationship with the NE system. Stress activates not only the HPA axis but also the locus ceruleus (LC) the major source of NE neurons in the brain $^{77}$. This activation leads to increased $\mathrm{NE}$ release during stress. LC neurons influence the neuroendocrine stress response system through their broad innervation of the paraventricular nucleus (PVN) projection pathways. Reciprocal interactions connecting cerebral NE and CRH systems may generate a "feed-forward" loop ${ }^{78}$. Severe anxiety in response to stress may be associated with NE overactivity and hyperactivity of the HPA axis, thus contributing to suicide 
risk $^{79}$. Dopamine modulates the HPA axis response to stress ${ }^{80,81}$. The DA system is particularly vulnerable to stress and even low intensity stressors, either acute or chronic, can activate DA neurons ${ }^{82,83}$. However, there is a paucity of data on these effects with respect to suicidal behavior. These interactions suggest multiple pathways through which stress may contribute to the biological anomalies observed in suicidal behavior, both directly through dysfunction of the HPA axis and the noradrenergic system and interactions between these two systems, as well as indirectly through downstream effects on serotonergic and possibly dopaminergic system function.

\section{Neuropsychological Endophenotypes}

Deficits in a range of cognitive domains including executive function, attention, language fluency, memory, problem solving and decision-making skills, and impulsiveness have been observed in association with suicidal behavior (reviewed in ${ }^{14}$ ). Attentional deficits are frequent in depressed individuals, but significantly more frequent in individuals who have attempted suicide ${ }^{14}$. Although attention may be affected globally in suicide attempters, performance on interference-type tasks can provide more specific information. The Stroop Test and the Continuous Performance Test (CPT) are reliable predictors of attentional deficits ${ }^{84,85}$. Although Stroop performance does not distinguish attempters and non-attempters ${ }^{14}$, greater effects are observed in the Stroop interference sub-score in depressed suicide attempters compared to depressed non-attempters ${ }^{86}$. Moreover, among depressed attempters, Stroop performance distinguish- es high- and low-lethality suicide attempters $^{86}$ suggesting that problems with executive control may be associated with more medically serious attempts ${ }^{14,86,87}$. Impairments on the Stroop interference task are indicative of difficulty shifting attention from "compelling but inappropriate" stimuli. In a suicidal individuals, such difficulty could predispose to attending to negative emotional states, such as pessimism and self-blame, and lead to action on such states ${ }^{14}$. Impaired attention may also underlie the cognitive rigidity that is a common clinical feature in suicide attempters ${ }^{14,88}$. In other attention studies, higher rates of CPT omission and commission errors were reported in adolescent suicide attempters compared to non-attempters ${ }^{89}$, however such differences were not observed among adults ${ }^{14}$.

\section{Genes and early-life environment}

Figure 1 indicates two factors at the outset of a putative causal chain leading to suicidal behavior: genetics and early-life adversity. In this section we will review findings that suggest that these two factors impact on both biological and consequently clinical intermediate phenotypes and indicate potential causal pathways leading to suicidal acts.

\section{Early-life environment}

Adverse events in early-life, including sexual or physical abuse, neglect, parental loss, or severe family discord, have been associated with suicidal behavior ${ }^{90,91}$. Sexual and physical abuse independently contribute to repeated suicide attempts after controlling for a range of other childhood adversities ${ }^{92}$. 
One pathway through which early-life adversity contributes to suicidal behavior later in life is through developmental effects on neurobiological systems that have functional consequences in adulthood. Evidence from both animal (see ${ }^{44}$ for a review), and human studies demonstrates lasting alterations in HPA axis ${ }^{93,94}$, and serotonergic ${ }^{95}$ and dopaminergic ${ }^{95,96}$ systems, associated with earlylife adversity. These alterations may in turn increase vulnerability for the development of psychiatric disorders ${ }^{97,98}$, stress sensitivity $^{96}$, and behavioral and personality traits such as impulsivity and aggression ${ }^{90}$ later in life, all of which are associated with increased risk for suicidal acts.

\section{Genes and Suicidal Behavior}

Twin, adoption, and family studies of suicidal behavior demonstrate a role of genetics in suicidal behavior independent from the presence of axis I or axis II disorders ${ }^{99}, 100$. Population based estimates of the contribution off additive genetic factors are between $30-50 \%$ for a broad phenotype of suicidal behavior that includes ideation, plans and attempts (see ${ }^{101}$ ), largely independent of the inheritance of psychiatric disorder. Twin studies report that the concordance rate for suicide in twins is higher in monozygotic $(24.1 \%)$ compared with dizygotic twins $(2.8 \%)^{101}$. Adoption studies reveal higher suicide rates in the biological parents of adoptees who died by suicide ${ }^{102,103}$, compared to biological parents of adoptees who did not. Offspring of depressed suicide attempters are more likely to become suicide attempters themselves compared to offspring of depressed non-attempters ${ }^{100}$.

Genetic research in suicidal behavior has included linkage studies, and single nucleotide polymorphism (SNP) association studies. Given the likelihood of a polygenic mode of inheritance ${ }^{104}$, more recent studies adopt novel methodologies involving functional genomics such as using microarray technologies to profile expression of thousands of genes simultaneously (for an overview see ${ }^{105}$ ), and genome wide arrays for hundreds of thousands of SNPs ${ }^{106}$. Candidate genes for SNP association studies have been selected largely based on the evidence from neurobiological studies in suicide. To date the serotonergic system has been the most extensively investigated, but other research targets have been the dopaminergic and noradrenergic systems, brain derived neurotrophic factor, and the HPA axis.

\section{Serotonergic system genes}

Specific polymorphisms of the $5-\mathrm{HT}_{2 \mathrm{~A}}$ receptor gene have been associated with suicide attempt in mood disorder patients, including the 102T-1438A and T102C polymorphisms (see Brezo et al. ${ }^{107}$ for a review). It is unknown if there is some synergistic effect of the two on suicidal behaviour, or if the latter may just be a marker of the former ${ }^{108}$. However, not all studies show consistent results, and meta-analysis of 25 studies found no association between $\mathrm{T} 102 \mathrm{C}$ polymorphism and suicide attempt or suicide ${ }^{109}$.

There is a relatively common polymorphism of the serotonin transporter gene (5HTTLPR) where the low expressing $S$ allele has been linked to decreased serotonin function in vitro ${ }^{110}$. Meta-analysis that included 12 studies comprising 1599 subjects found a significant association of the 5-HTTLPR low expressing $\mathrm{S}$ allele and suicidal behavior ${ }^{109}$. However, studies of the 5-HTTLPR genotype and serotonergic function in suicide have been few. In studies examining 5-HTTLPR and serotonin transporter density in 
postmortem brains individuals who died by suicide one reported an association ${ }^{111}$ and four did not ${ }^{33,112-114}$. A recent SPECT study in a small sample of male suicide attempters found that the $\mathrm{S}$ allele was associated with lower transporter availability in suicide attempters but not in controls ${ }^{115}$. Other imaging studies have examined brain function more generally, with respect to 5-HTTLPR genotype (see Brown \& Hariri ${ }^{116}$ for a review). In healthy adults, multiple studies report that individuals with the lower expressing SS genotype show increased amygdala activity when exposed to angry or fearful faces, negative words, or aversive pictures ${ }^{117-}$ 122. The amygdala has a central in role in encoding of emotional memories, emotional regulation and responses to stress ${ }^{123}$, and is densely innervated by serotonergic neurons and 5-HT receptors are abundant ${ }^{124-126}$.

Tryptophan hydroxylase (TPH) is the rate-limiting enzyme in the synthesis of serotonin. Two variants have been described: TPH1 and TPH $2^{127}$. Some, but not all, studies reported TPH1 SNP associations with suicidal behavior ${ }^{128}$, and aggression ${ }^{129}$ (see Baldessarini \& Hennen ${ }^{130}$ for a review). For TPH2, haplotype studies in psychiatric samples report associations with suicide ${ }^{131}$ and suicide attempt ${ }^{132,133}$, and single SNP studies report associations between TPH2 genotype and suicidal behavior in Chinese ${ }^{134}$ and German Caucasian ${ }^{135}$ psychiatric samples, but many others fail to observe any associations ${ }^{107}$. Potential endophenotypes for the expression of the TPH 2 gene are suggested in studies that find genotype association with decreased executive function ${ }^{136,137}$ and attention $^{136}$, altered amygdala response ${ }^{138}$ and, in an fMRI, study altered functioning in prefrontal and parietal brain regions associated with working memory ${ }^{139}$.

Several studies have shown an association between alterations in the monoamine oxi- dase A (MAOA) gene and aggression ${ }^{140,141}$, an element in the diathesis for suicidal behavior. Additionally, the MAOA-uVNTR polymorphism has been associated higher impulsivity in males ${ }^{142}$. Because the gene for MAOA is sex linked, it is hypothesized that the higher rate of suicides among males could be due to greater impulsivity and aggression, secondary to specific MAOA polymorphisms ${ }^{143}$. An fMRI study found that the low expressing alleles of the u-VNTR were associated with increased risk of violent behavior and with alterations in the corticolimbic circuitry involved in affect regulation, emotional memory and impulsivity ${ }^{144}$. In two other fMRI studies MAOA genotype affected performance on response tasks indicative of impulsivity ${ }^{145,146}$.

\section{Other genes}

The catechol-O-methyltransferase (COMT) enzyme is a major enzyme in NE activation. COMT activity is affected by a single nucleotide polymorphism at codon 158 (COMT-Val/Met 158) where the allele encoding a valine residue (Val allele) is associated with higher catalytic activity compared with the allele encoding a methionine residue (Met allele) ${ }^{147}$. Some authors suggest that this polymorphism might modify not the susceptibility to, but the clinical course of suicidal behavior making it more violent and lethal ${ }^{148}$. Recent meta-analysis of 519 cases and 933 controls from 6 studies found suggestive evidence of an association between COMT-Val/Met 158 polymorphism and suicidal behavior, perhaps related to the lethality of suicide attempt ${ }^{149}$. Supporting this are reports of association between the low functioning Met allele and impulsive aggression in schizophrenia ${ }^{150-152}$ and violent suicide attempts ${ }^{153}$. 
The noradrenergic and dopaminergic systems, HPA axis, and neurotrophic factor BDNF have also been examined for candidate genes, with no consistent associations yet identified (for an overview see Rujescu et al. $\left.{ }^{154}\right)$.

\section{Genes and Early-Life environment}

The disparate findings in genetic association studies may in part be attributable to differences in environmental characteristics of study samples. Pre-clinical studies demonstrate that early-life adversity interacts with genotype and the resultant biological and behavioral alterations endure into adulthood $^{155,156}$. In humans, there have been multiple studies of early-life environment/ 5-HTTLPR interaction and vulnerability for psychiatric disorder, with most, but not all, reporting an effect (see Uher ${ }^{157}$ for a review). With respect to suicidal behavior, Caspi et al found that among individuals who had experienced childhood maltreatment, only those with the low expressing $\mathrm{S}$ 5-HTTLPR allele were at risk for suicidal ideation and suicide attempt ${ }^{158}$. Other studies of the 5-HTTLPR report childhood adversity-genotype interactions and suicidal behavior in mixed diagnosis inpatients ${ }^{159}$ and among abstinent African American substance dependent patients ${ }^{160}$. Adverse childrearing, in combination with a lower expressing variant of the MAO A gene was also found to contribute, in males only, to the development of antisocial behavior and more impulsivity, both of which may contribute to suicidal behavior ${ }^{142,161}$.

It is likely that such effects occur with genes related to the other neurobiological systems involved in suicidal behavior, for exam- ple, a recent study found an interaction effect between CRH Receptor 1 haplotype gene and early-life stress on the severity of depres$\operatorname{sion}^{162}$. That study did not examine suicide related outcomes, however it is suggestive of another potential pathway whereby genes and environment contribute to vulnerability for suicidal behavior. More recently, preclinical studies have begun to investigate epigenetic mechanisms such as methylation as a pathway through which environment interacts with genetics to influence biological development and behavioral outcomes ${ }^{163}$.

\section{Therapeutic Implications}

Suicide prevention is possible as up to $83 \%$ of individuals who die by suicide have had contact with a primary care physician in the year prior to their death ${ }^{164}$. However, despite the development of theoretical models, it is not yet possible to reliably predict suicide and suicide attempt. However, the approach described here may allow better identification of high-risk populations. Studies of predictive utility of the two most extensively investigated biological alterations in suicidal behavior, CSF 5-HIAA and DST nonsuppression, have resulted in low positive predictive values for suicide, mainly due to lack of specificity but also because of the low base rates of suicide. Improvement in predicting suicide risk may involve combining several risk factors. Both biological and clinical prospective studies suggest that combining information obtained from two markers (i.e. CSF 5HIAA and DST results and aggression/impulsivity and pessimism) were better predictors than either marker alone ${ }^{22,27}$. Further studies that utilize a combination of biological and clinical markers may prove even more successful. 


\section{Summary and Conclusions}

An individual's risk of suicide and/or suicide attempt stems from the interaction between the diathesis, or predisposition, for suicidal behavior, and the occurrence of triggers ${ }^{17}$. The diathesis may comprise traits in the clinical, neurobiological, neurocognitive, genetic, behavioral, and personality domains. Via different pathways, these will affect the way in which an individual responds to stressful life events that may act as triggers for a suicidal act. Due to the complexity and multi-determined nature of suicidal behavior, a model that can integrate a number of risk factors identified as endophenotypes for suicidal behavior may better facilitate identification of high risk populations and thereby identify targets for intervention.

\section{Acknowledgments}

This study was supported by PHS grants MH059710, MH062185 and MH056390.

\section{References}

1. WHOSIS. WHO Statistical Information System (WHOSIS). Evidence and information for health policy. WHO Statistics 2003. World Health Organization.

2. Center for Disease Control. CDC. Web-based Injury Statistics Query and Reporting System (WISQARS ${ }^{\mathrm{TM}}$ ). National Center for Injury Prevention and Control. 2007. US Department of Health and Human Services, CDC.

3. Centers for Disease Control. Youth Risk Behavior Surveillance - United States, 2007. Morbidity and Mortality Weekly Report 57, 1-60 (no. SS-4). 6-6-2008.

4. Goldsmith SK, Pellmar TC, Kleinman AM, Bunney WE. Reducing Suicide. A National Imperative. Washington, DC: The National Academies Press; 2002.
5. Nock MK, Borges G, Bromet EJ, Cha CB, Kessler RC, Lee S. Suicide and suicidal behavior. Epidemiol Rev 2008; 30133-30154.

6. Chen YW, Dilsaver SC. Lifetime rates of suicide attempts among subjects with bipolar and unipolar disorders relative to subjects with other Axis I disorders. Biol Psychiatry 1996; 39(10): 896-899.

7. Chignon JM, Cortes MJ, Martin P, Chabannes JP. Attempted suicide and alcohol dependence: results of an epidemiologic survey. Encephale 1998; 24(4): 347-354.

8. Driessen M, Veltrup C, Weber J, John U, Wetterling T, Dilling H. Psychiatric co-morbidity, suicidal behaviour and suicidal ideation in alcoholics seeking treatment. Addiction 1998; 93(6): 889-894.

9. Preuss UW, Schuckit MA, Smith TL, Danko GP, Buckman K, Bierut L, et al. Comparison of 3190 alcoholdependent individuals with and without suicide attempts. Alcohol Clin Exp Res 2002; 26(4): 471-477.

10. Asnis GM, Friedman TA, Sanderson WC, Kaplan ML, van Praag HM, Harkavy Friedman JM. Suicidal behaviors in adult psychiatric outpatients, I: Description and prevalence. Am J Psychiatry 1993; 150(1): 108-112.

11. Cohen S, Lavelle J, Rich CL, Bromet E Rates and correlates of suicide attempts in first-admission psychotic patients. Acta Psychiatr Scand 1994; 90167-90171.

12. Radomsky ED, Haas GL, Mann JJ, Sweeney JA. Suicidal behavior in patients with schizophrenia and other psychotic disorders. Am J Psychiatry 1999; 156(10): 1590-1595.

13. Kessler RC, Borges G, Walters EE. Prevalence of and risk factors for lifetime suicide attempts in the National Comorbidity Survey. Arch Gen Psychiatry 1999; 56(7): 617-626.

14. Keilp JG, Gorlyn M, Oquendo MA, Burke AK, Mann JJ. Attention deficit in depressed suicide attempters. Psychiatry Res 2008; 159(1-2): 7-17.

15. Oquendo MA, Currier D, Mann JJ. Prospective studies of suicidal behavior in major depressive and bipolar disorders: what is the evidence for predictive risk factors? Acta Psychiatr Scand 2006; 114(3): 151-158.

16. Mann JJ. Neurobiology of suicidal behaviour. Nat Rev Neurosci 2003; 4(10): 819-828.

17. Mann JJ, Waternaux C, Haas GL, Malone KM. Toward a clinical model of suicidal behavior in psychiatric patients. Am J Psychiatry 1999; 156(2): 181-189.

18. Mann JJ, Currier D. Suicide and Attempted Suicide. In: Fatemi SH, Clayton PJ, editors. The Medical Basis of Psychiatry. Philadelphia, PA: Humana Press; 2008. p. 561-576. 
19. Gottesman II, Gould T. The endophenotype concept in psychiatry: etymology and strategic intentions. Am J Psychiatry 2003; 160(4): 636-645.

20. Mann JJ, Arango VA, Avenevoli S, Brent DA, Champagne FA, Clayton P, et al. Candidate Endophenotypes for Genetic Studies of Suicidal Behavior. Biol Psychiatry 2009; 65(7): 556-563.

21. Congdon E, Canli T. A neurogenetic approach to impulsivity. J Pers 2008; 76(6): 1447-1483.

22. Oquendo MA, Galfalvy H, Russo S, Ellis SP, Grunebaum MF, Burke A, et al. Prospective study of clinical predictors of suicidal acts after a major depressive episode in patients with major depressive disorder or bipolar disorder. Am J Psychiatry 2004; 161(8): 1433-1441.

23. Nordström P, Samuelsson M, Åsberg M, TräskmanBendz L, Aberg-Wistedt A, Nordin C, et al. CSF 5-HIAA predicts suicide risk after attempted suicide. Suicide Life Threat Behav 1994; 24(1): 1-9.

24. Mann JJ, Brent DA, Arango V. The neurobiology and genetics of suicide and attempted suicide: a focus on the serotonergic system. Neuropsychopharmacology 2001; 24(5): 467-477.

25. Pandey GN, Dwivedi Y, Rizavi HS, Ren X, Pandey $\mathrm{SC}$, Pesold C, et al. Higher expression of serotonin 5$\mathrm{HT}(2 \mathrm{~A})$ receptors in the postmortem brains of teenage suicide victims. Am J Psychiatry 2002; 159(3): 419-429.

26. Oquendo MA, Placidi GP, Malone KM, Campbell C, Keilp J, Brodsky B, et al. Positron emission tomography of regional brain metabolic responses to a serotonergic challenge and lethality of suicide attempts in major depression. Arch Gen Psychiatry 2003; 60(1): 14-22.

27. Mann JJ, Currier D, Stanley B, Oquendo MA, Amsel LV, Ellis SP. Can biological tests assist prediction of suicide in mood disorders? Int J Neuropsychopharmacol 2006; 9(4): 465-474.

28. Jones JS, Stanley B, Mann JJ, Frances AJ, Guido JR, Träskman-Bendz L, et al. CSF 5-HIAA and HVA concentrations in elderly depressed patients who attempted suicide. Am J Psychiatry 1990; 147(9): 1225-1227.

29. Cooper SJ, Kelly CB, King DJ. 5-Hydroxyindoleacetic acid in cerebrospinal fluid and prediction of suicidal behaviour in schizophrenia. Lancet 1992; 340(8825): 940-941.

30. Mann JJ, Malone KM. Cerebrospinal fluid amines and higher-lethality suicide attempts in depressed inpatients. Biol Psychiatry 1997; 41(2): 162-171.

31. Sher L, Carballo JJ, Grunebaum MF, Burke AK, Zalsman G, Huang YY, et al. A prospective study of the association of cerebrospinal fluid monoamine metabolite levels with lethality of suicide attempts in patients with bipolar disorder. Bipolar Disord 2006; 8(5 Pt 2): 543-550.

32. Arango V, Underwood MD, Gubbi AV, Mann JJ. Localized alterations in pre- and postsynaptic serotonin binding sites in the ventrolateral prefrontal cortex of suicide victims. Brain Res 1995; 688(1-2): 121-133.

33. Mann JJ, Huang YY, Underwood MD, Kassir SA, Oppenheim S, Kelly TM, et al. A serotonin transporter gene promoter polymorphism (5-HTTLPR) and prefrontal cortical binding in major depression and suicide. Arch Gen Psychiatry 2000; 57(8): 729-738.

34. Austin MC, Bradley CC, Mann JJ, Blakely RD. Expression of serotonin transporter messenger RNA in the human brain. J Neurochem 1994; 62(6): 2362-2367.

35. Leyton M, Paquette V, Gravel P, Rosa-Neto P, Weston F, Diksic M, et al. alpha-[11C]Methyl-L-tryptophan trapping in the orbital and ventral medial prefrontal cortex of suicide attempters. Eur Neuropsychopharmacol 2006; 16(3): 220-223.

36. van Heeringen C, Audenaert K, Van Laere K, Dumont F, Slegers G, Mertens J, et al. Prefrontal 5-HT2a receptor binding index, hopelessness and personality characteristics in attempted suicide. J Affect Disord 2003; 74(2): 149-158.

37. Ryding E, Lindstrom M, Traskman-Bendz L. The role of dopamine and serotonin in suicidal behaviour and aggression. Prog Brain Res 2008; 172: 307-315.

38. Tiihonen J, Kuikka JT, Bergström KA, Karhu J, Lehtonen J, Hallikainen T, et al. Single-photon emission tomography imaging of monoamine transporters in impulsive violent behaviour. Eur J Nucl Med 1997; 24(10): 1253-1260.

39. Parsey RV, Oquendo MA, Simpson NR, Ogden RT, Van Heertum R, Arango V, et al. Effects of sex, age, and aggressive traits in man on brain serotonin 5- HT(1A) receptor binding potential measured by PET using [C11]WAY- 100635. Brain Res 2002; 954(2): 173-182.

40. Meyer JH Imaging the serotonin transporter during major depressive disorder and antidepressant treatment. J Psychiatry Neurosci 2007; 32(2): 86-102.

41. Carballo JJ, Harkavy-Friedman J, Burke AK, Sher L, Baca-Garcia E, Sullivan GM, et al. Family history of suicidal behavior and early traumatic experiences: additive effect on suicidality and course of bipolar illness? J Affect Disord 2008; 109(1-2): 57-63.

42. Bhagwagar Z, Hinz R, Taylor M, Fancy S, Cowen P, Grasby P. Increased 5-HT(2A) receptor binding in euthymic, medication-free patients recovered from depression: a positron emission study with [(11)C]MDL 100,907. Am J Psychiatry 2006; 163(9): 1580-1587. 
43. Arango V, Underwood MD, Mann JJ. Fewer pigmented locus coeruleus neurons in suicide victims: Preliminary results. Biol Psychiatry 1996; 39(2): 112-120.

44. Heim C, Nemeroff CB. The role of childhood trauma in the neurobiology of mood and anxiety disorders: preclinical and clinical studies. Biol Psychiatry 2001; 49(12): 1023-1039.

45. Ordway GA, Widdowson PS, Smith KS, Halaris A. Agonist binding to $\mathrm{a}_{2}$-adrenoceptors is elevated in the locus coeruleus from victims of suicide. J Neurochem 1994; 63(2): 617-624.

46. Arango V, Ernsberger P, Sved AF, Mann JJ. Quantitative autoradiography of $\mathrm{a}_{1}$ - and $\mathrm{a}_{2}$-adrenergic receptors in the cerebral cortex of controls and suicide victims. Brain Res 1993; 630(1-2): 271-282.

47. Weiss GK, Ratner A, Voltura A, Savage D, Lucero $\mathrm{K}$, Castillo N. The effect of two different types of stress on locus coeruleus alpha- 2 receptor binding. Brain Res Bull 1994; 33(2): 219-221.

48. Agren H, Niklasson F. Suicidal potential in depression: focus on CSF monoamine and purine metabolites. Psychopharmacol Bull 1986; 22(3): 656-660.

49. Virkkunen M, De Jong J, Bartko J, Linnoila M. Psychobiological concomitants of history of suicide attempts among violent offenders and impulsive fire setters. Arch Gen Psychiatry 1989; 46(7): 604-606.

50. Lester D. The concentration of neurotransmitter metabolites in the cerebrospinal fluid of suicidal individuals: a meta-analysis. Pharmacopsychiat 1995; 28(2): 45-50.

51. Traskman-Bendz L, Alling C, Oreland L, Regnell G, Vinge E, Ohman R. Prediction of suicidal behavior from biologic tests. J Clin Psychopharmacol 1992; 12(2 Suppl): 21S-26S.

52. Engstrom G, Alling C, Blennow K, Regnell G, Traskman-Bendz L. Reduced cerebrospinal HVA concentrations and HVA/5-HIAA ratios in suicide attempters. Monoamine metabolites in 120 suicide attempters and 47 controls. Eur Neuropsychopharmacol 1999; 9(5): 399-405.

53. Sunnqvist C, Westrin A, Traskman-Bendz L: Suicide attempters: biological stressmarkers and adverse life events. Eur Arch Psychiatry Clin Neurosci 2008; 258(8): 456-462.

54. Galfalvy H, Currier D, Oquendo MA, Sullivan G, Huang YY, Mann JJ. Lower CSF MHPG prdicts short-term risk for suicide attempt. International Journal of Neuropsychopharmacology 2009. 12(10): 1327-1335.

55. Prochazka H, Agren H. Self-rated aggression and cerebral monoaminergic turnover. Sex differences in pa- tients with persistent depressive disorder. Eur Arch Psychiatry Clin Neurosci 2003; 253(4): 185-192.

56. Miller HL, Delgado PL, Salomon RM, Berman R, Krystal JH, Heninger GR, et al. Clinical and biochemical effects of catecholamine depletion on antidepressant-induced remission of depression. Arch Gen Psychiatry 1996; 53(2): 117-128.

57. Henn FA, Vollmayr B. Stress models of depression: forming genetically vulnerable strains. Neurosci Biobehav Rev 2005; 29(4-5): 799-804.

58. Dailly E, Chenu F, Renard CE, Bourin M. Dopamine, depression and antidepressants. Fundam Clin Pharmacol 2004; 18(6): 601-607.

59. Stoff DM, Mann JJ Suicide research. Overview and introduction. Ann N Y Acad Sci 1997; 836: 1-11.

60. Bowden C, Cheetham SC, Lowther S, Katona CL, Crompton MR, Horton RW. Reduced dopamine turnover in the basal ganglia of depressed suicides. Brain Res 1997; 769(1): 135-140.

61. Bowden C, Theodorou AE, Cheetham SC, Lowther $\mathrm{S}$, Katona CLE, Crompton MR, et al. Dopamine $\mathrm{D}_{1}$ and $\mathrm{D}_{2}$ receptor binding sites in brain samples from depressed suicides and controls. Brain Res 1997; 752(1-2): 227-233.

62. Roy A, De Jong J, Linnoila M. Cerebrospinal fluid monoamine metabolites and suicidal behavior in depressed patients. A 5-year follow-up study. Arch Gen Psychiatry 1989; 46(7): 609-612.

63. Placidi GP, Oquendo MA, Malone KM, Huang YY, Ellis SP, Mann JJ. Aggressivity, suicide attempts, and depression: relationship to cerebrospinal fluid monoamine metabolite levels. Biol Psychiatry 2001; 50(10): 783-791.

64. Sher L, Mann JJ, Traskman-Bendz L, Winchel R, Huang YY, Fertuck E, et al. Lower cerebrospinal fluid homovanillic acid levels in depressed suicide attempters. J Affect Disord 2006; 90(1): 83-89.

65. Lee IH, Cheng CC, Yang YK, Yeh TL, Chen PS, Chiu NT Correlation between striatal dopamine D2 receptor density and neuroticism in community volunteers. Psychiatry Res 2005; 138(3): 259-264.

66. Nemeroff $\mathrm{CB}$. The neurobiology of aging and the neurobiology of depression: Is there a relationship? Neurobiol Aging 1988; 9: 120-122.

67. Arato M, Banki CM, Bissette G, Nemeroff CB. Elevated CSF CRF in suicide victims. Biol Psychiatry 1989; 25(3): 355-359.

68. Coryell W, Schlesser M. The dexamethasone suppression test and suicide prediction. Am J Psychiatry 2001; 158(5): 748-753. 
69. Coryell W, Young E, Carroll B. Hyperactivity of the hypothalamic-pituitary-adrenal axis and mortality in major depressive disorder. Psychiatry Res 2006; 142(1): 99-104.

70. Mann JJ, Currier D. A review of prospective studies of biologic predictors of suicidal behavior in mood disorders. Arch Suicide Res 2007; 11(1): 3-16.

71. Brunner J, Stalla GK, Stalla J, Uhr M, Grabner A, Wetter TC, et al. Decreased corticotropin-releasing hormone $(\mathrm{CRH})$ concentrations in the cerebrospinal fluid of eucortisolemic suicide attempters. J Psychiatr Res 2001; 35(1): 1-9.

72. van Heeringen K, Audenaert K, Van de WL, Verstraete A. Cortisol in violent suicidal behaviour: association with personality and monoaminergic activity. J Affect Disord 2000; 60(3): 181-189.

73. Meltzer HY, Perline R, Tricou BJ, Lowy M, Robertson A. Effect of 5-hydroxytryptophan on serum cortisol levels in major affective disorders. II. Relation to suicide, psychosis, and depressive symptoms. Arch Gen Psychiatry 1984; 41(4): 379-387.

74. Meijer OC, De Kloet ER. Corticosterone and serotonergic neurotransmission in the hippocampus: Functional implications of central corticosteriod receptor diversity. Critical Reviews in Neurobiology 1998; 12(1\&2): 1-20.

75. Owens MJ, Nemeroff CB. Physiology and pharmacology of corticotropin-releasing factor. Pharmacol Rev 1991; 43425-43473.

76. Lopez JF, Vazquez DM, Chalmers DT, Watson SJ. Regulation of 5-HT receptors and the hypothalamic-pituitary-adrenal axis. Implications for the neurobiology of suicide. Ann N Y Acad Sci 1997; 836: 106-134.

77. Aston-Jones G, Shipley MT, Chouvet G, Ennis M, van Bockstaele E, Pieribone V, et al. Afferent regulation of locus coeruleus neurons: anatomy, physiology and pharmacology. Prog Brain Res 1991; 88: 47-75.

78. Dunn AJ, Swiergiel AH, Palamarchouk V. Brain circuits involved in corticotropin-releasing factor-norepinephrine interactions during stress. Ann N Y Acad Sci 2004; 1018: 25-34.

79. Brown RP, Stoll PM, Stokes PE, Frances A, Sweeney J, Kocsis JH, et al. Adrenocortical hyperactivity in depression: effects of agitation, delusions, melancholia, and other illness variables. Psychiatry Res 1988; 23(2): 167-178.

80. Spencer SJ, Ebner K, Day TA. Differential involvement of rat medial prefrontal cortex dopamine receptors in modulation of hypothalamic-pituitary-adrenal axis responses to different stressors. Eur J Neurosci 2004; 20(4): 1008-1016.
81. Brake WG, Flores G, Francis D, Meaney MJ, Srivastava LK, Gratton A. Enhanced nucleus accumbens dopamine and plasma corticosterone stress responses in adult rats with neonatal excitotoxic lesions to the medial prefrontal cortex. Neuroscience 2000; 96(4): 687-695.

82. Horger BA, Roth RH. The role of mesoprefrontal dopamine neurons in stress. Crit Rev Neurobiol 1996; 10(3-4): 395-418.

83. Vermetten E, Bremner JD. Circuits and systems in stress. I. Preclinical studies. Depress Anxiety 2002; 15(3): 126-147.

84. Goldberg E, Bougakov D Neuropsychologic assessment of frontal lobe dysfunction. Psychiatr Clin North Am 2005; 28(3): 567-569.

85. Riccio CA, Reynolds CR. Continuous performance tests are sensitive to ADHD in adults but lack specificity. A review and critique for differential diagnosis. Ann N Y Acad Sci 2001; 931: 113-139.

86. Keilp JG, Sackeim HA, Brodsky BS, Oquendo MA, Malone KM, Mann JJ. Neuropsychological dysfunction in depressed suicide attempters. Am J Psychiatry 2001; 158(5): 735-741.

87. Nasser EH, Overholser JC. Assessing varying degrees of lethality in depressed adolescent suicide attempters. Acta Psychiatr Scand 1999; 99(6): 423-431.

88. Pollock LR, Williams JM. Problem-solving in suicide attempters. Psychol Med 2004; 34(1): 163-167.

89. Horesh N. Self-report vs. computerized measures of impulsivity as a correlate of suicidal behavior. Crisis 2001; 22(1): 27-31.

90. Brodsky BS, Stanley B. Adverse childhood experiences and suicidal behavior. Psychiatr Clin North Am 2008; 31(2): 223-235.

91. Fergusson DM, Horwood LJ, Lynskey MT. Childhood sexual abuse and psychiatric disorder in young adulthood: II. Psychiatric outcomes of childhood sexual abuse. J Am Acad Child Adolesc Psychiatry 1996; 35(10): 13651374.

92. Ystgaard M, Hestetun I, Loeb M, Mehlum L. Is there a specific relationship between childhood sexual and physical abuse and repeated suicidal behavior? Child Abuse Negl 2004; 28(8): 863-875.

93. Heim C, Newport DJ, Bonsall R, Miller AH, Nemeroff $\mathrm{CB}$. Altered pituitary-adrenal axis responses to provocative challenge tests in adult survivors of childhood abuse. Am J Psychiatry 2001; 158(4): 575-581.

94. De Bellis MD, Chrousos GP, Dorn LD, Burke L, Helmers K, Kling MA, et al. Hypothalamic-pituitary- 
adrenal axis dysregulation in sexually abused girls. J Clin Endocrinol Metab 1994; 78(2): 249-255.

95. Roy A. Self-rated childhood emotional neglect and CSF monoamine indices in abstinent cocaine-abusing adults: possible implications for suicidal behavior. Psychiatry Res 2002; 112(1): 69-75.

96. Pruessner JC, Champagne F, Meaney MJ, Dagher A. Dopamine release in response to a psychological stress in humans and its relationship to early life maternal care: a positron emission tomography study using [11C]raclopride. J Neurosci 2004; 24(11): 2825-2831.

97. Widom CS. Posttraumatic stress disorder in abused and neglected children grown up. Am J Psychiatry 1999; 156(8): 1223-1229.

98. Widom CS, DuMont K, Czaja SJ. A prospective investigation of major depressive disorder and comorbidity in abused and neglected children grown up. Arch Gen Psychiatry 2007; 64(1): 49-56.

99. Brent DA, Mann JJ. Family genetic studies, suicide, and suicidal behavior. Am J Med Genet C Semin Med Genet 2005; 133(1): 13-24.

100. Brent DA, Melhem N. Familial transmission of suicidal behavior. Psychiatr Clin North Am 2008; 31(2): 157-177.

101. Voracek M, Loibl LM. Genetics of suicide: a systematic review of twin studies. Wien Klin Wochenschr 2007; 119(15-16): 463-475.

102. Schulsinger F, Kety SS, Rosenthal D, Wender PH. A Family Study of Suicide. In: Schou M, Stromgren E, edis. Origin, Prevention and Treatment of Affective Disorders. New York: Academic Press; 1979. p. 277-287.

103. Wender PH, Kety SS, Rosenthal D, Schulsinger F, Ortmann J, Lunde I. Psychiatric disorders in the biological and adoptive families of adopted individuals with affective disorders. Arch Gen Psychiatry 1986; 43(10): 923-929.

104. Papadimitriou GN, Linkowski P, Delarbre C, Mendlewicz J. Suicide on the paternal and maternal sides of depressed patients with a lifetime history of attempted suicide. Acta Psychiatr Scand 1991; 83(6): 417-419.

105. Sequeira A, Turecki G. Genome wide gene expression studies in mood disorders. OMICS 2006; 10(4): 444454 .

106. Hodgkinson CA, Yuan Q, Xu K, Shen PH, Heinz E, Lobos EA, et al. Addictions Biology: Haplotype-Based Analysis for 130 Candidate Genes on a Single Array. Alcohol Alcohol 2008; 43(5): 505-515.

107. Brezo J, Klempan T, Turecki G. The genetics of suicide: a critical review of molecular studies. Psychiatr Clin North Am 2008; 31(2): 179-203.
108. Vaquero-Lorenzo C, Baca-Garcia E, Diaz-Hernandez M, Perez-Rodriguez MM, Fernandez-Navarro P, Giner L, et al. Association study of two polymorphisms of the serotonin-2A receptor gene and suicide attempts. Am J Med Genet B Neuropsychiatr Genet 2008; 147B(5): 645649.

109. Anguelova M, Benkelfat C, Turecki G. A systematic review of association studies investigating genes coding for serotonin receptors and the serotonin transporter: II. Suicidal behavior. Mol Psychiatry 2003; 8(7): 646-653.

110. Lesch KP, Bengel D, Heils A, Sabol SZ, Greenberg $\mathrm{BD}$, Petri S, et al. Association of anxiety-related traits with a polymorphism in the serotonin transporter gene regulatory region. Sci 1996; 274(5292): 1527-1531.

111. Du L, Faludi G, Palkovits M, Demeter E, Bakish D, Lapierre YD, et al. Frequency of long allele in serotonin transporter gene is increased in depressed suicide victims. Biol Psychiatry 1999; 46(2): 196-201.

112. Arango V, Underwood MD, Mann JJ. Serotonin brain circuits involved in major depression and suicide. Prog Brain Res 2002; 136(35): 443-453.

113. Parsey RV, Hastings RS, Oquendo MA, Hu X, Goldman D, Huang YY, et al. Effect of a triallelic functional polymorphism of the serotonin-transporter-linked promoter region on expression of serotonin transporter in the human brain. Am J Psychiatry 2006; 163(1): 48-51.

114. Oquendo MA, Hastings RS, Huang YY, Simpson $\mathrm{N}$, Ogden RT, Hu XZ, et al. Brain serotonin transporter binding in depressed patients with bipolar disorder using positron emission tomography. Arch Gen Psychiatry 2007; 64(2): 201-208.

115. Bah J, Lindstrom M, Westberg L, Manneras L, Ryding E, Henningsson S, et al. Serotonin transporter gene polymorphisms: effect on serotonin transporter availability in the brain of suicide attempters. Psychiatry Res 2008; 162(3): 221-229.

116. Brown SM, Hariri AR. Neuroimaging studies of serotonin gene polymorphisms: exploring the interplay of genes, brain, and behavior. Cogn Affect Behav Neurosci 2006; 6(1): 44-52.

117. Hariri AR, Mattay VS, Tessitore A, Kolachana B, Fera F, Goldman D, et al. Serotonin transporter genetic variation and the response of the human amygdala. Sci 2002; 297(5580): 400-403.

118. Furmark T, Tillfors M, Garpenstrand H, Marteinsdottir I, Langstrom B, Oreland L, et al. Serotonin transporter polymorphism related to amygdala excitability and symptom severity in patients with social phobia. Neurosci Lett 2004; 362(3): 189-192. 
119. Canli T, Omura K, Haas BW, Fallgatter A, Constable RT, Lesch KP. Beyond affect: a role for genetic variation of the serotonin transporter in neural activation during a cognitive attention task. Proc Natl Acad Sci U S A 2005; 102(34): 12224-12229.

120. Heinz A, Braus DF, Smolka MN, Wrase J, Puls I, Hermann D, et al. Amygdala-prefrontal coupling depends on a genetic variation of the serotonin transporter. Nat Neurosci 2005; 8(1): 20-21.

121. Hariri AR, Drabant EM, Munoz KE, Kolachana BS, Mattay VS, Egan MF, et al. A susceptibility gene for affective disorders and the response of the human amygdala. Arch Gen Psychiatry 2005; 62(2): 146-152.

122. Bertolino A, Arciero G, Rubino V, Latorre V, De Candia M, Mazzola V, et al. Variation of human amygdala response during threatening stimuli as a function of 5'HTTLPR genotype and personality style. Biol Psychiatry 2005; 57(12): 1517-1525.

123. LeDoux JE. Emotion circuits in the brain. Annu Rev Neurosci 2000; 23: 155-184.

124. Azmitia EC, Gannon PJ. The primate serotonergic system: a review of human and animal studies and a report on Macaca fascicularis. Adv Neurol 1986; 43: 407-468.

125. Sadikot AF, Parent A. The monoaminergic innervation of the amygdala in the squirrel monkey: an immunohistochemical study. Neuroscience 1990; 36(2): 431-447.

126. Smith HR, Daunais JB, Nader MA, Porrino LJ. Distribution of $[3 \mathrm{H}]$ citalopram binding sites in the nonhuman primate brain. Ann NY Acad Sci 1999; 877: 700-702.

127. Walther DJ, Peter JU, Bashammakh S, Hortnagl H, Voits M, Fink H, et al. Synthesis of serotonin by a second tryptophan hydroxylase isoform. Sci 2003; 299(5603): 76.

128. Bellivier F, Chaste P, Malafosse A. Association between the TPH gene A218C polymorphism and suicidal behavior: a meta-analysis. Am J Med Genet 2004; 124B(1): 87-91.

129. Rujescu D, Giegling I, Bondy B, Gietl A, Zill P, Moller HJ. Association of anger-related traits with SNPs in the TPH gene. Mol Psychiatry 2002; 7(9): 1023-1029.

130. Baldessarini RJ, Hennen J Genetics of suicide: an overview. Harv Rev Psychiatry 2004; 12(1): 1-13.

131. Zill P, Buttner A, Eisenmenger W, Moller HJ, Bondy B, Ackenheil M. Single nucleotide polymorphism and haplotype analysis of a novel tryptophan hydroxylase isoform (TPH2) gene in suicide victims. Biol Psychiatry 2004; 56(8): 581-586.

132. Zhou Z, Roy A, Lipsky R, Kuchipudi K, Zhu G, Taubman J, et al. Haplotype-based linkage of tryptophan hydroxylase 2 to suicide attempt, major depression, and cerebrospinal fluid 5-hydroxyindoleacetic acid in 4 populations. Arch Gen Psychiatry 2005; 62(10): 1109-1118.

133. Lopez VA, Detera-Wadleigh S, Cardona I, Kassem L, McMahon FJ. Nested association between genetic variation in tryptophan hydroxylase II, bipolar affective disorder, and suicide attempts. Biol Psychiatry 2007; 61(2): 181-186.

134. Ke L, Qi ZY, Ping Y, Ren CY. Effect of SNP at position 40237 in exon 7 of theTPH2 gene on susceptibility to suicide. Brain Res 2006; 1122(1): 24-26.

135. Zill P, Baghai TC, Zwanzger P, Schule C, Eser D, Rupprecht R, et al. SNP and haplotype analysis of a novel tryptophan hydroxylase isoform (TPH2) gene provide evidence for association with major depression. Mol Psychiatry 2004; 9(11): 1030-1036.

136. Reuter M, Ott U, Vaitl D, Hennig J. Impaired executive control is associated with a variation in the promoter region of the tryptophan hydroxylase 2 gene. J Cogn Neurosci 2007; 19(3): 401-408.

137. Manor I, Laiba E, Eisenberg J, Meidad S, Lerer E, Israel S, et al. Association between tryptophan hydroxylase 2, performance on a continuance performance test and response to methylphenidate in ADHD participants. Am J Med Genet B Neuropsychiatr Genet 2008; 147B(8): 1501-1508.

138. Furmark T, Appel L, Henningsson S, Ahs F, Faria $\mathrm{V}$, Linnman C, et al. A link between serotonin-related gene polymorphisms, amygdala activity, and placebo-induced relief from social anxiety. J Neurosci 2008; 28(49): 1306613074.

139. Reuter M, Esslinger C, Montag C, Lis S, Gallhofer B, Kirsch P. A functional variant of the tryptophan hydroxylase 2 gene impacts working memory: a genetic imaging study. Biol Psychol 2008; 79(1): 111-117.

140. Brunner HG, Nelen M, Breakefield XO, Ropers $\mathrm{HH}$, van Oost BA. Abnormal behavior associated with a point mutation in the structural gene for monoamine oxidase A. Sci 1993; 262(5133): 578-580.

141. Cases O, Seif I, Grimsby J, Gaspar P, Chen K, Pournin S, et al. Aggressive behavior and altered amounts of brain serotonin and norepinephrine in mice lacking MAOA. Sci 1995; 268(5218): 1763-1766.

142. Huang YY, Cate SP, Battistuzzi C, Oquendo MA, Brent D, Mann JJ. An association between a functional polymorphism in the monoamine oxidase a gene promoter, impulsive traits and early abuse experiences. Neuropsychopharmacology 2004; 29(8): 1498-1505.

143. Du L, Faludi G, Palkovits M, Sotonyi P, Bakish D, Hrdina PD. High activity-related allele of MAO-A gene associated with depressed suicide in males. Neuroreport 2002; 13(9): 1195-1198. 
144. Meyer-Lindenberg A, Buckholtz JW, Kolachana B, Hariri R, Pezawas L, Blasi G, et al. Neural mechanisms of genetic risk for impulsivity and violence in humans. Proc Natl Acad Sci U S A 2006; 103(16): 6269-6274.

145. Passamonti L, Fera F, Magariello A, Cerasa A, Gioia MC, Muglia M, et al. Monoamine oxidase-a genetic variations influence brain activity associated with inhibitory control: new insight into the neural correlates of impulsivity. Biol Psychiatry 2006; 59(4): 334-340.

146. Fan J, Fossella J, Sommer T, Wu Y, Posner MI. Mapping the genetic variation of executive attention onto brain activity. Proc Natl Acad Sci U S A 2003; 100(12): 74067411.

147. Lachman HM, Papolos DF, Saito T, Yu YM, Szumlanski CL, Weinshilboum RM. Human catechol-O-methyltransferase pharmacogenetics: description of a functional polymorphism and its potential application to neuropsychiatric disorders. Pharmacogenetics 1996; 6(3): 243-250.

148. Rujescu D, Giegling I, Gietl A, Hartmann AM, Moller HJ. A functional single nucleotide polymorphism (V158M) in the COMT gene is associated with aggressive personality traits. Biol Psychiatry 2003; 54(1): 34-39.

149. Kia-Keating BM, Glatt SJ, Tsuang MT. Metaanalyses suggest association between COMT, but not HTR1B, alleles, and suicidal behavior. Am J Med Genet B Neuropsychiatr Genet 2007; 144B(8): 1048-1053.

150. Lachman HM, Nolan KA, Mohr P, Saito T, Volavka J. Association between catechol O-methyltransferase genotype and violence in schizophrenia and schizoaffective disorders. Am J Psychiatry 1998; 155(6): 835-837.

151. Kotler M, Barak P, Cohen H, Averbuch IE, Grinshpoon A, Gritsenko I, et al. Homicidal behavior in schizophrenia associated with a genetic polymorphism determining low catechol O-methyltransferase (COMT) activity. Am J Med Genet 1999; 88(6): 628-633.

152. Strous RD, Bark N, Parsia SS, Volavka J, Lachman HM. Analysis of a functional catechol-O-methyltransferase gene polymorphism in schizophrenia: evidence for association with aggressive and antisocial behavior. Psychiatry Res 1997; 69(2-3): 71-77.

153. Nolan KA, Volavka J, Czobor P, Cseh A, Lachman $\mathrm{H}$, Saito T, et al. Suicidal behavior in patients with schizophrenia is related to COMT polymorphism. Psychiatr Genet 2000; 10(3): 117-124.

154. Rujescu D, Thalmeier A, Moller HJ, Bronisch T, Giegling I. Molecular genetic findings in suicidal behavior: what is beyond the serotonergic system? Arch Suicide Res 2007; 11(1): 17-40.
155. Bennett AJ, Lesch KP, Heils A, Long JC, Lorenz JG, Shoaf SE, et al. Early experience and serotonin transporter gene variation interact to influence primate CNS function. Mol Psychiatry 2002; 7(1): 118-122.

156. Barr CS, Newman TK, Shannon C, Parker C, Dvoskin RL, Becker ML, et al. Rearing condition and rh5HTTLPR interact to influence limbic-hypothalamic-pituitary-adrenal axis response to stress in infant macaques. Biol Psychiatry 2004; 55(7): 733-738.

157. Uher R, McGuffin P. The moderation by the serotonin transporter gene of environmental adversity in the aetiology of mental illness: review and methodological analysis. Mol Psychiatry 2008; 13(2): 131-146.

158. Caspi A, Sugden K, Moffitt TE, Taylor A, Craig IW, Harrington $\mathrm{H}$, et al. Influence of life stress on depression: moderation by a polymorphism in the 5-HTT gene. Sci 2003; 301(5631): 386-389.

159. Gibb BE, McGeary JE, Beevers CG, Miller IW. Serotonin transporter (5-HTTLPR) genotype, childhood abuse, and suicide attempts in adult psychiatric inpatients. Suicide Life Threat Behav 2006; 36(6): 687-693.

160. Roy A, Hu XZ, Janal MN, Goldman D. Interaction between childhood trauma and serotonin transporter gene variation in suicide. Neuropsychopharmacology 2007; 32(9): 2046-2052.

161. Caspi A, McClay J, Moffitt TE, Mill J, Martin J, Craig IW, et al. Role of genotype in the cycle of violence in maltreated children. Sci 2002; 297(5582): 851-854.

162. Bradley RG, Binder EB, Epstein MP, Tang Y, Nair HP, Liu W, et al. Influence of child abuse on adult depression: moderation by the corticotropin-releasing hormone receptor gene. Arch Gen Psychiatry 2008; 65(2): 190-200.

163. Weaver IC, Cervoni N, Champagne FA, D’Alessio AC, Sharma S, Seckl JR, et al. Epigenetic programming by maternal behavior. Nat Neurosci 2004; 7(8): 847-854.

164. Mann JJ, Apter A, Bertolote J, Beautrais A, Currier D, Haas A, et al. Suicide prevention strategies: a systematic review. J Am Med Assoc 2005; 294(16): 2064-2074.

Corresponding author:

Maria A. Oquendo, M.D.

Division of Molecular Imaging \& Neuropathology

Department of Psychiatry

New York State Psychiatric Institute/Columbia University 1051 Riverside Drive, Unit 42

New York 10032

Telephone: 212-543-6774

Fax: 212-543-6017

E-mail:mao4@columbia.edu 